\title{
From Liberalism to Liberalisation: International Electricity Governance in the Twentieth Century
}

Citation for published version (APA):

Lagendijk, V. (2014). From Liberalism to Liberalisation: International Electricity Governance in the Twentieth Century. In M. Schiefelbusch, \& H-L. Dienel (Eds.), Linking Networks: The Formation of Common Standards and Visions for Infrastructure Development (pp. 137-150). Ashgate.

https://doi.org/10.4324/9781315592497-16

Document status and date:

Published: 01/01/2014

DOI:

10.4324/9781315592497-16

Document Version:

Publisher's PDF, also known as Version of record

Document license:

Taverne

Please check the document version of this publication:

- A submitted manuscript is the version of the article upon submission and before peer-review. There can be important differences between the submitted version and the official published version of record.

People interested in the research are advised to contact the author for the final version of the publication, or visit the DOI to the publisher's website.

- The final author version and the galley proof are versions of the publication after peer review.

- The final published version features the final layout of the paper including the volume, issue and page numbers.

Link to publication

\footnotetext{
General rights rights.

- You may freely distribute the URL identifying the publication in the public portal. please follow below link for the End User Agreement:

www.umlib.nl/taverne-license

Take down policy

If you believe that this document breaches copyright please contact us at:

repository@maastrichtuniversity.nl

providing details and we will investigate your claim.
}

Copyright and moral rights for the publications made accessible in the public portal are retained by the authors and/or other copyright owners and it is a condition of accessing publications that users recognise and abide by the legal requirements associated with these

- Users may download and print one copy of any publication from the public portal for the purpose of private study or research.

- You may not further distribute the material or use it for any profit-making activity or commercial gain

If the publication is distributed under the terms of Article $25 \mathrm{fa}$ of the Dutch Copyright Act, indicated by the "Taverne" license above, 


\section{Chapter 9 \\ 2 - 2 \\ 3 From Liberalism to Liberalisation: $\quad 3$ \\ 4 International Electricity Governance in the 4 \\ 5 International Electricity Governance in the 5 Twentieth Century 7 \\ Vincent Lagendijk

14 Behind the wall socket electrons move across borders with ease, empowering 14 15 electronic machinery and appliances wherever and whenever needed. Electricity 15 16 systems within the European realm are well-integrated both materially and 16 17 institutionally. While electricity moves around Europe with relative ease, 17 18 consumers sometimes experience some friction; travelling around Europe one 18 19 encounters at least six different wall plugs. The need for adapters to different 19 20 plugs might very well be the only friction left in Europe's electricity system. ${ }^{1}$ The 20 21 contrast with electricity itself could not be greater.

22 This integrated system has two dimensions. First, there is a material dimension. 22 23 Electricity is a grid-based system, where the grid is used for transmission and 23 24 distribution of electric power (Kaijser 2003, p. 155). A sufficient technological 24 25 sophistication is necessary to build transmission lines and transformation stations, 25 26 and to enable the flow of electrons across borders. This implies that equipment 26 27 on both sides of the border need to be compatible with each other, directly or via 27 28 an adapter. Technical standards need to be agreed upon, or interface technologies 28 29 needed to be developed, in order to facilitate integration of electricity systems. 29 30 Without it the system simply cannot not perform.

31 A second dimension is institutional; 'rules of the game' need to be established. 31

32 These are partially incorporated in a legal framework, and in a set of more informal 32

33 rules and principles which can be called the 'rules of the system'. ${ }^{2}$ These needs to 33

34 correspond with the goal and aims of the system at hand. These aims can range 34 35 from primary ones like providing an uninterrupted electricity supply, to secondary 35 36 ones like competition between electricity providers. These two dimensions are not 36 37 constant; they evolve to lessen friction to more integration across borders. Friction 37

1 This status quo is official policy since 1990, as the costs of change and the 39

41 risks during a lengthy transition to a universal system do not outweigh its benefits. See 40

41 (CENELEC and Winckler 1994, p. 150).

422 'Rules of the game' is inspired by the work of North (North 1990). 'Rules of the 42

43 system' is based on the thoughts of Tom Hughes, who argues that large technological 43

44 systems are based on a technical core as well as on an organisational structure. 
1 in this chapter refers to legislative, political and technological features hampering 1

2 international electricity exchanges.

3 This chapter compares two periods; from the late nineteenth century to 3

4 the Interwar period, with the post-World War II period. Both are subdivided 4

5 into two eras. The first era comprises the early years of electricity, lasting until 5

6 World War I. The second era - Interwar years - was characterised by a contested 6

7 process of legislation. The second period concerns the post-Second World 7

8 War recovery and reconfiguration, which gives way to the fourth era starting 8

9 approximately in 1975, which is marked by market liberalisation impulses from 9

10 the European Commission. 10

11 The focus is on the governance of international electricity connections. 11

12 According to Rosenau the advent of new technologies shrink social, economic, 12

13 political and geographical spaces, but also create new problems. Governance 13

14 answers to these challenges and is here defined as 'the activities of governments, 14

15 but it also includes the many other channels through which 'commands' flow in 15

16 the form of goals framed, directives issues, and policies pursued' (Rosenau 1995, 16

17 pp. 14, 16). Thomas Hughes has argued that all elements - technological ones 17

18 and others - contribute to the system goal (Hughes 1987, p. 51). In the case of the 18

19 electricity system not only technological aims (securing a cost-efficient electricity 19

20 supply) but also socio-political aims are at work, as pointed out by Pfaffenberger 20

21 (Pfaffenberger 1990, p. 364). He claims that political values are embedded in 21

22 technologies; these values are part of a discourse which determines the strength of 22

23 these values (Pfaffenberger 1992, pp. 382-4). Such a discourse is constructed by 23

24 policy-makers as well as in part by engineers that build and govern the system. ${ }^{3} \quad 24$

25 The chapter argues that three major governance shifts - namely, during 25

26 the Interwar, post-Second World War, and since the 1970s - were the result of 26

27 changed thinking about system goals - both technological and socio-political 27

28 ones. These shifts were directed at influencing international electricity exchanges. 28

29 The main thrust for change came from different actors. The chapter continues 29

30 in a chronological order, followed by a conclusion which compares the Interwar 30

31 period with the post-World War II period, and ends pondering about possible 31

32 future governance changes. 32

35 1. Before the War: From Liberalism to Regulation 35

37 The first power plants and transmission lines appeared during the last decade 37

38 of the nineteenth century. Cross-border electricity transmission immediately 38

39 took place between European countries, as there was little friction to integration 39

40 on a limited scale. On the contrary even, there were at least three incentives to 40

$42-3$ Jeffrey Herf has pointed out that engineers often act as ideologues, and that they 42

43 sometimes pursued ideological aims, even when these conflicted with engineering rationality 43

44 itself. See (Herf 1984, pp. 152-4). This theme is further developed in (Lagendijk 2012). 
1 go beyond national borders. First, shared resources like the Rhine also formed 1

2 political boundaries, and developing the river thus implied sharing the benefits. 2

3 This necessitates novel forms of international cooperation. 3

4 Second, most electrical utilities closely coordinated their activities with 4

5 industrial consumers to ensure a good load factor. Load factor is the ratio of the 5

6 average load to the maximum load, best visualised as a curve where peaks are at 6

7 times of large electricity consumption, and valleys when demand is low. In short, 7

8 the 'flatter' the curve, the better the load factor. The challenge for power station 8

9 managers is finding a customer base leading to a constant load, even if this means 9

10 meeting energy demands across national border (Hughes 1987, pp. 51-82, 71). 10

11 A third incentive for international cooperation concerned reaping the benefits 11

12 of combining various types of electricity production. Each type of electricity 12

13 generation has its own characteristics. Coal-fired plants are capable of providing a 13

14 stable flow, but at relatively high and fluctuating running fuel costs. Hydro-power 14

15 depends on the availability of water. This varies per season but has very little 15

16 running costs after high initial investments. It is thus preferable to use hydro power 16

17 instead of burning coal whenever possible. Striking a favourable balance between 17

18 various resources - a good economic mix - can be profitable, even across borders. 18

19 Finally, security of supply was favourably affected collaborating across 19

20 borders. By integrating regional networks incidents like malfunctions in plants 20

21 or the network can be tackled with more ease as there is more capacity available 21

22 to cover for immediate shortages. This became increasingly important over the 22

23 course of the twentieth century as the socio-economic importance of electricity 23

24 substantially increased. 24

25 Cross-border flows of electricity are possible once certain conditions are 25

26 met. One of these is technological. In the early years of the twentieth century 26

27 electricity, 60-70 kilovolt $(\mathrm{kV})$ lines were used which only had a limited economic 27

28 range. The introduction of higher transmission capacities (110 and later 22028

$29 \mathrm{kV}$ ) during the Interwar period, and up to 400 and $600 \mathrm{kV}$ after World War 29

30 II) limited transport losses, and made it economically interesting to expand the 30

31 geographical scale of cooperation. Standardisation was stimulated by emerging 31

32 engineering organisations, pioneered by the International Electro-Technical 32

33 Commission (IEC, 1906). Further international professional organisations sprang 33

34 up between the wars, institutionalisation of knowledge and technology exchange 34

35 occurred (International Electrotechnical Commission 1906). By the 1920s, most 35

36 Western European networks had adopted a frequency of $50 \mathrm{~Hz}$ (Varaschin 1997, 36

37 p. 142). 37

38 Another condition is regulatory; legislation and international agreements 38

39 should not hamper the flow of electricity. Before World War I no international 39

40 regulation existed for international electricity flows, and neither governments nor 40

41 international organisations infringed with the governance of such flows. This left 41

42 the initiative to private actors, mostly powerful alliances between manufacturers 42

43 of electrical equipment on the one hand and banks on the other. This would 43

44 
1 significantly change after World War I, and continue to transform ever more after 1

2 World War II. 2

5 2. Interwar Electricity Regulation

7 After World War I changes took place in the electricity regime on both national 7 8 and international levels. National authorities increasingly gained control over 8

9 the electricity sector after World War I. For one, this was related to the changing 9

10 economic tide. New legislation for international electricity flows were modelled 10

11 after the overall economic protectionist measures. During the war various 11

12 government bodies came to run specific economic sectors in order to overcome 12

13 shortages. After the war engineers and policy-makers agreed that further rational 13

14 utilisation of resources and organisation of the sector was necessary. This also 14

15 helped to lower the 'additional costs' of foreign finance and to decrease external 15

16 dependence in general. As a consequence the interconnection of networks and 16

17 rationalisation remained priorities, but ever more within the boundaries of nations 17

18 (Hausman et al. 2008, pp. 125, 127-9). 18

19 Therefore, in most European countries, authorities assumed some form 19

20 of oversight over in- and outbound flows of electricity, and began to develop 20

21 transmission networks and production capacity, in particular of hydroelectricity. 21

22 This not only concerned import and export regulations and concession systems, 22

23 but also included laws making watercourses 'national', and restricting their 23

24 accessibility to foreign investors. ${ }^{4}$

25 Electricity was also regarded as an instrument for social advancement. 25

26 National and regional authorities came to see electricity as a national public 26

27 service (Bouneau et al. 2007, p. 35). National electricity laws aimed to expand 27

28 production capacity, to interconnect regional electricity systems, and to encourage 28

29 a wider distribution of electricity. Especially rural areas were electrified in the 29

30 name of social and economic progress, and sometimes for electoral purposes 30

31 (Varaschin 1997, p. 35; Coutard 2001). 31

32 While national authorities issued restrictive legislation, international attempts 32

33 were made to provide conventions for electricity transmission across borders. 33

34 The League of Nations (LoN, 1919) was the pioneer in this regard, especially 34

35 its Organisation for Communications and Transit (OCT). It dealt with a variety 35

36 of transport modes (road, rail, maritime, inland waterways, air), and aimed to 36

37 standardise and provide international regulatory regimes through conventions. ${ }^{5} 37$

38 Electricity matters came to be part of the OCT's work due to discussions about 38

404 A rather complete overview of European legislation is given in Siegel 1930. 40

415 See Schipper et al. 2010. Communications at that time was not equated to 41

42 telecommunications, but to means of transport. Telecommunications was a minor part 42

43 of League activities, but mostly reserved for other international organisations. For the 43

44 League's activities concerning radio, see Fleury 1983. 
1 railways. $^{6}$ While discussing the electrification of railways of international 1

2 importance, the cross-border movement of electricty over overhead lines 2

3 divided the members. The Italian delegation proposed that countries with large 3

4 hydroelectricity resources should be responsible for the traction. Although the 4

5 suggestion was rejected the OCT thought the issue should be further studied, as 5

6 international electricity transmission concerned one aspect 'of the much wider 6

7 [...] question of the value of international agreements in assisting to bring about 7 8 a rational exploitation of power [...]' (League of Nations 1923a, Annex 7, p. 33). 8

9 This study materialised in a 1923 report. While underlining the novelty of 9

10 international, the study provided two very general draft conventions. The first 10

11 was an attempt to settle matters of international transmission and transit of 11

12 electricity. In general, the study suggested, all measures and solutions should 12

13 fit within the 'limits of national laws' (League of Nations 1923b, p. 5). This 13

14 includes the construction of new lines and installations, either directly by states 14

15 or concessionary companies. The choices made for new transmission lines should 15

16 be technical considerations, and not political ones or national frontiers. Transit of 16

17 electricity should be free of special dues, apart from charges for expenses made. 17

18 The second Convention concerned the development of hydroelectric power in 18

19 international watercourses. It aimed to arrange the construction of power plants 19

20 in rivers or lakes with two or more riparian states. The production of new plants 20

21 should be arranged and divided between these states, and installations in the river 21

22 should not hamper navigation. 22

23 Only a handful of states ratified the Conventions; four for the one on 23

24 transmission in transit, and five for the one on development of hydraulic power on 24

25 international watercourses (Mance 1946, pp. 148-50). This provoked a response 25

26 from internationally-oriented electrical engineers, many of which argued for a 26

27 laisser-faire regime for international electricity transmission. One prominent 27

28 engineer claimed that international connections 'can never have any but a useful 28

29 and beneficial effect from all point of view' (Landry 1926, p. 1117). From 192929

30 onwards engineers started to advocate a European network, giving this liberal 30

31 regime a specific geographical dimension. At the same time, this allowed them to 31

32 form an alliance with European-minded politicians favouring European economic 32

33 and political unification (Lagendijk 2008, Chapter 3; Lagendijk 2012). Though 33

34 many electrical engineers disagreed with constructing a European supergrid, most 34

35 did favour a more liberal international regime within the European realm. $\quad 35$

$36 \quad 36$

$\begin{array}{ll}37 & 37\end{array}$

38 3. Post-World War II Electricity Regulation 38

$39 \quad 39$

40 Several elements re-emerged after World War II. The first was thinking in terms 40

41 of 'Europe'. A post-war consensus emerged among electrical engineers who ran 41

$42 \quad 42$

436 Van Laak has argued that the railroad was 'the formative model of modern 43

44 infrastructure'. See Laak 2004, p. 58. 
1 the national systems. This implied that network operators continued to think in 1

2 terms of European optimisation and rationalisation - a second continuity. This 2

3 was further bolstered by the Marshall Plan. Post-war planners, and not just the 3

4 Americans, clearly realised that electricity was quickly becoming an increasingly 4

5 important contributor to economic growth. 5

6 While the Marshall Plan aiming for rapid European economic reconstruction, 6

7 it promoted closer European cooperation as a means to do so. Part of the support 7

8 for the electricity sector hence was earmarked to foster closer collaboration 8

9 between European countries. A collaborative body for electricity eventually 9

10 grew out of the Marshall Plan: the informal and engineering organisation the 10

11 Union for the Coordination of the Production and Transmission of Electricity 11

12 (UCPTE). It successfully plead for a relaxation of formal rules of inter-state 12

13 electricity exchanges between 1951 and 1956, a process the UCPTE labelled as 13

14 'liberalisation' (Lagendijk 2011, p. 297). This governance shift thus pushed for 14

15 more international exchanges, and was led by engineers. 15

16 Most of the resultant electricity exchange were in service of the national 16

17 electricity supply system. The shared safety measures were designed to isolate 17

18 incidents locally, and preventing them from spreading to neighbouring regions and 18

19 countries. Other form of collaboration aimed to cover seasonal shortages (often 19

20 exchanged for seasonal hydroelectricity surpluses) and coordination of power 20

21 plant maintenance. With electricity increasingly permeating society, the (both 21

22 economic and non-economic) costs of a power failure were becoming higher. 22

23 UCPTE therefore made strong efforts to the secure electricity supply. This is 23

24 illustrated by Table 9.1. Although the actual exchange of electricity across borders 24

25 grew annually, the proportion in terms of national consumption was actually quite 25

26 low and fluctuating yearly. 26

$\begin{array}{ll}27 & 27\end{array}$

$28 \quad 28$

29 Table 9.1 Electricity Exchange within the UCPTE, * 1967-1985 29

$30 \longrightarrow 30$

$\begin{array}{llllllll}31 & \text { YEAR } & 1967 & 1970 & 1975 & 1980 & 1985 & 31\end{array}$

$\begin{array}{llllllll}32 & \text { Absolute growth in \% } & 5.6 & 6.1 & 5.6 & 7.0 & 7.7 & 32\end{array}$

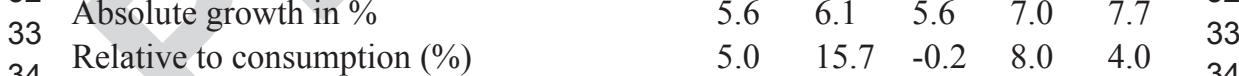

$35 \longrightarrow 35$

$\begin{array}{ll}35 & \text { Source: UCPTE Annual Reports. } \\ 36 & 35 \\ 37 & \end{array}$

$36 *$ The UCPTE members in this period are Austria, Belgium, France, the Federal Republic $\begin{aligned} & 36 \\ & 37 \text { of Germany, Italy, Luxemburg, and the Netherlands }\end{aligned}$
37

38 of 38

$39 \quad 39$

40 While delegating powers to the UCPTE, national (and sub-national) authorities 40

41 nevertheless kept control over the electricity sector. During the Interwar period 41

42 governments stepped up as regulators, they now also increasingly became 42

43 (co-)owners. The financial and political instability of the 1930s already seriously 43

44 hurt the private actors in the electricity sector and fractured organisational structures. 44 
1 In some countries - like Austria, France, Spain and Italy, and most Central and 1

2 Eastern European countries - the patchwork of regional and local electricity 2

3 companies was integrated into a publicly owned 'giant', and foreign elements were 3

4 removed from the sector. This meant the end of the presence of the multinational 4

5 electricity enterprises. In other countries governments directly stimulated electricity 5

6 production and distribution (Hausman et al. 2008, pp. 223, 236-7). 6

7 During the first decades after World War II, most barriers to international 7

8 electricity flows were removed by the engineer-dominated UCPTE. This process 8

9 of liberalisation primarily served the (sub-)national systems, and fitted with 9

10 the post-war strategy of national policy-makers. The necessary technological 10

11 integration did however lead to a closely integrated European system, operating 11

12 according to similar technical parameters. Optimising the national systems thus 12

13 required international cooperation as well as the removal of friction to cross-border 13

14 exchanges. It thus makes sense to speak of a liberal-national system of governance. 14

$15 \quad 15$

$16 \quad 16$

17 4. The 1970s: A New European Governance 17

$18 \quad 18$

19 Another impulse for electricity cooperation came from the European integration 19

20 process that started with the European Coal and Steel Community (ECSC, 1951). 20

21 In the negotiations resulting in the Treaties of Rome (1957), establishing the 21

22 Common Market as well as the Atomic Energy Community, the need for a common 22

23 energy policy for the Community was identified (CACEU 1955). Abundant and 23

24 cheaper energy was seen as a cornerstone of economic progress. The existing 24

25 common market for coal have to be extended to include oil, gas and electricity. 25

26 These energy carriers would also have to compete with each other. 26

27 In the eventual 1957 Treaty electricity (as was gas) was excluded. Discussions 27

28 within the preparatory committee on energy made clear that electricity was not a 28

29 'normal' commodity that could become part of the Common Market. The fact that 29

30 electricity was network-bounded and its movement determined by laws of physics 30

31 disqualified it from inclusion in the Common Market (CACEU 1955). Trading 31

32 electricity is fundamentally different from regular goods; it cannot be efficiently 32

33 stored and its movements are bound by laws of physics. In essence, electricity was 33

34 never traded but exchanged - a transaction form resembling clearance. 34

35 The final report nevertheless identified the energy sector (including electricity) 35

36 in need of Community action, in order to ensure a sufficient energy production. 36

37 Progressively and gradually the various energy forms - like coal - should be 37

38 included into the Common Market (Comité Intergouvernemental créé par la 38

39 Conférence de Messine 1956, pp. 126-9). In subsequent years the European 39

40 Commission (EC) indeed made several attempts to forge a common energy policy, 40

41 and as a part of that, introducing competition in the sector. These attempts were 41

42 mostly false starts until 1985 (Padgett 1992, p. 56). The main hurdle were the 42

43 existing domestic structures, acting as inert and a strong countervailing forces 43

44 (Eising and Jabko 2001, pp. 744, 748). National and sub-national government 44 
1 hold considerable stakes and interests in the energy sector as a whole. Authorities 1

2 extract significant taxes from energy sales, and intervene in the sector to achieve 2

3 broad social, economic and industrial aims. More recently they seek to fulfil (parts 3

4 of) their environmental policy (Helm 2002, p. 174). 4

5 In 1985 the EC's Single European Act aimed to complete the Common Market 5

6 by 1992, and electricity was a part of that effort (Matláry 1997). To make electricity 6

7 part of the Common Market the institutional needed to change. A main aim would 7

8 then be lower energy prices for consumers through competition. Competition 8

9 would be enabled by breaking the monopoly of the sector, by liberalising the 9

10 electricity system. This involved network access to third parties, and breaking 10

11 up the integrated aspects of transmission and production of electricity. National 11

12 networks, since World War I the near exclusive domain of domestic actors, would 12

13 also be opened to foreign competitors.

14 Ending these national monopolies, the EC argued, would transform the sector 14

15 into an open internal market, whereby electricity is produced on a competitive 15

16 basis. Electricity should be subject to Community policy regarding environmental 16

17 protection and energy in general (Commission of the European Communities 1988, 17

18 p. 70). Differences of fiscal and financial preferences to utilities, as well as state 18

19 support, had to be harmonised within the Community. The same applied to ownership 19

20 structures of network ownership and national electricity pricing systems. The 20

21 latter in particular should become more transparent (Commission of the European 21

22 Communities 1988, pp. 71, 74). The main benefits were to be an increase in energy 22

23 trade between member states, an enhanced security of supply, reduced energy costs, 23

24 and a further rationalisation of the sector (Padgett 1992, p. 57).

25 This governance shift had serious consequences for international electricity 25

26 transfers. Now rationalisation would not be limited to within nations but also 26

27 across European borders, as national markets were opened to foreign and new 27

28 players. This second phase of liberalisation was European in character. 28

29 This paradigm shift in how to govern infrastructural systems like electricity had 29

30 to shifting visions on efficiency. Over the course of the 1970s several international 30

31 actors - including the World Bank and the International Monetary Fund - began 31

32 to see state-ran companies and strongly regulated industries as inefficient. Since 32

33 the 1980s the most potential appeared to be in market-style competition and 33

34 unbundling of transmission and production functions (Hausman et al. 2008, 34

35 p. 263). Soon after various governments engaged in privatisation and deregulation 35

36 'experiments' across the globe, notably in Chile, the United Kingdom as well as in 36

37 New Zealand and the United States. In addition, large energy consumers wanted 37

38 to be more independent in choosing their energy suppliers (Gilbert et al. 1996; 38

39 Eising 2002; Lagendijk 2011).

40 In addition to changing perspectives on system rationality, novel technological 40

41 developments made these institutional adjustments possible. Electricity system 41

42 became increasingly permeated with information technology devices, like sensors, 42

43 computers, relays, and communication lines. Due to these developments, electricity 43

44 could be better guided through the network and safeguarded the electricity supply 44 
1 to consumers, and allowed monitoring the system for irregularities and sharing of 1

2 information as in the Supervisory Control and Data Acquisition system. On the 2

3 basis of these real-time data, attributing a price to a certain amount of electricity 3

4 has become a lot easier, as well as determining its 'path' through the network 4

5 (Thue, forthcoming).

6 The existing institutional flag-bearer UCPTE did not immediately cede to the 6

7 EC's plans. The UCPTE claimed that the industry itself had taken the initiative 7

8 to liberalise cross-border electricity flows in the $1950 \mathrm{~s}$, which had put the 8

9 sector ahead of other sectors (UCPTE 1988, p. 95; Lagendijk 2011). Yet there 9

10 overarching aim had always been efficiency as well as making the system as robust 10

11 as possible, by building in safety measures in order to ensure a reliable electricity 11

12 supply. Yet finally giving in this organisation transformed itself and assumed two 12

13 new primary tasks. First, it focused upon system security in the new situation 13

14 by establishing technical rules for system operation related to interconnected 14

15 synchronous operation in the membership area. Second, it held a close watch on 15

16 system adequacy through supplying information to members, market players, and 16

17 authorities (UCTE 2002, p. 27). In this way, it helped to change the institutional 17

18 dimensions of the electricity system from security-oriented to a trade-centred 18

19 within the European Union. 19

20 The time-table set in 2003 for further liberalisation implied that the electricity 20

21 market should be open to all non-household consumers by July 1, 2004, and to all 21

22 customers by July 1, 2007 (European Commission 2001, p. 11). Today, at least 22

23 according to a UCPTE president, "electricity has [...] assumed the characteristics 23

24 of a branded commodity, to which it is now possible to assign a name, or even a 24

25 colour', it being green, wind, or atomic electricity (UCTE 2000, p. 5). We only 25

26 need the occasional adapter to actually tap into it. 26

$\begin{array}{ll}27 & 27\end{array}$

$28 \quad 28$

29 5. Conclusions $\square 29$

$30 \quad 30$

31 How can we, finally, compare and contrast the eras before and after World 31

32 War II? In sum, the main governance shifted from liberal to nationalistic after 32

33 World War I, and from nationalistic to liberal-national after World War II, and 33

34 eventually under influence of the EC, to liberal-European since the 1970s. This is 34

35 schematically represented in Table 9.2. With these shifts, the geographical unit of 35

36 optimisation changed, and a new dominant group of actors was able to change the 36

37 system's aim. $\quad 37$

38 During the liberal era, technological limits restrained electricity supply to the 38

39 local level. Despite the limit economic range, electricity flowed across borders 39

40 unhampered by a lack of regulation. Contrary to other infrastructural systems, 40

41 electricity networks did not quite represent a Europe of Nation-States until 1914. 41

42 Multinational enterprises, and not national authorities, were the main actor in the 42

43 electricity sector. Connections across borders were built by them, helped by an 43

44 early standardisation effort. 
1 Table 9.2 Electricity Governance Eras 1

2

3

4

5

6

20 led to further integration of regional systems and further rationalisation. At the 20

21 same time, national authorities started to guard domestic energy resources against 21

22 foreign elements. These new regulations left less room for multinational enterprises 22

23 and restricted the international flow of electricity. In sum, the important socio- 23

24 political aims inherent in the electricity system were nurturing national growth 24

25 and remaining economic independent in terms of energy. This legislative 'friction' 25

26 limited the possibilities of international exchanges.

27 This is the balance sheet of the period lasting until to World War II. The 27

28 liberalism prior to the Great War, with some cross-border connections, was 28

29 replaced by nationalism as domestic interests were prioritised. This development 29

30 did not go uncontested. Against the nationalistic grain international organisations 30

31 claimed a larger role. Both professional associations as well as intergovernmental 31

32 organisations argued for more liberal electricity regime. Although their calls went 32

33 largely unheard, a consensus emerged among engineers that a gradual construction 33

34 of a European system was the way to go, and this should go accompanied with a 34

35 liberal system. Engineers saw this as a type of European integration to overcome 35

36 the 'friction' caused by nationally-inspired restrictions.

37 The national economy remained important in the liberal-national era after 37

38 World War II, but now opened up in order to use European cooperation to 38

39 optimise and secure the domestic electricity supply. In other words, the balance 39

40 between national priorities and international cooperation altered. In post-war 40

41 years an integrated Europe became a widely shared aim among policy-makers 41

42 and experts alike. Stimulated through the Marshall Plan, an informal body was 42

43 founded to facilitate international electricity cooperation between western 43

44 European countries, the UCPTE. The expert-led UCPTE successfully lobbied 44 
1 against national restrictions to international electricity flows in the $1950 \mathrm{~s}$. Within 1

2 the electricity sector a particular type of European integration was devised. 2

3 Although the emerging national systems were technologically closely connected, 3

4 cross-border connections were primarily used to optimise and secure the supply 4

5 of national systems.

6 A second fundamental governance shift appears in the 1970s. A second vector 6

7 of European integration, initiated in the 1950s, launched proposals for a deepening 7

8 and widening of European cooperation also initially included electricity. 8

9 This gained momentum as paradigms about the efficiency of state-controlled 9

10 sectors changed, energy-intensive industries longed for more competition, and 10

11 technological advances provided more detailed and real-time data to determine 11

12 prices, and allowed for more control on flows within the system. The EC envisioned 12

13 a common energy market where competition between producers and forms of 13

14 energy would lead to more efficiency and lower prices. This opened up a new era 14

15 of liberalisation, where efficiency on the European level was the main aim. $\quad 15$

$16 \quad 16$

$17-17$

18 6. More Change to Come? 18

1919

20 Like electricity, its governance, too, always seems to be in flux. More change 20

21 is bound to come, as in recent years new pressures for further governance 21

22 adjustments are increasing. Challenges include climate change, leading the EU to 22

23 set sustainability and CO2 emission reductions targets for 2020, and the renewed 23

24 doubts about the viability of nuclear energy, due to the recent incidents in the 24

25 Japanese nuclear power stations at Fukushima. These pressures provide incentives 25

26 for a search for alternative forms of energy suppliers, both in terms of technology 26

$\begin{array}{ll}27 \text { as well as geography. } & 27\end{array}$

28 In general, two trends can be observed. A first trend is the increased attention for 28

29 decentralised electricity generation like solar panels, wind turbines, and combined 29

30 heat and power applications. On the one hand local and small-scale units can have 30

31 positive environmental benefits and help improve security of supply. On the other, 31

32 however, such units are often unpredictable and volatile in terms of production, 32

33 which can lead to overcapacity on local networks. In addition, the introduction 33

34 of more decentralised generation is hampered by regulatory barriers (Pepermans 34

35 et al. 2005). Governance changes are thus required. 35

36 The second trend concerns a number of plans, a number of proposal are put 36

37 forward, resembling the Interwar super-grid idea. One example is Desertec that 37

38 aims to harvest the Saharan sun with gigantic fields of photovoltaic cells. Related 38

39 plans, like Airtricity, envision large wind farm in the North Sea (Clery 2010; 39

40 Von Hirschhausen 2010). Both require a considerable strengthening of network 40

41 connections and capacity, and would lead to a significant increase in cross-border 41

42 flows. As approval procedures are slow, a policy response here, too, seems to 42

43 be necessary. Whether and how this will translate into a new era of electricity 43

44 governance remains an open question. 
1 References 1

3 Bouneau, C., Derdevet, M. and Percebois, J., 2007. Les réseaux électriques au 3

4 coeur de la civilisation industrielle, Boulogne: Timée-Editions. 4

5 CENELEC and Winckler, R., 1994. Electrotechnical Standardization in Europe: A 5

6 Tool for the Internal Market, Brussels: Cenelec. 6

7 Central Archives of the Council of the European Union, Brussels (CACEU), fonds 3: 7

8 Negotiations for the Treaties institutionalising the EEC and EURATOM, File 8

9 Nego 65: Comité Intergouvernemental créé par la Conférence de Messine, 9

10 Commission de l'énergie classique. Projet de rapport, MAE 441 f/55 mvo, 10

11 October 10, 1955.

12 Clery, D., 2010. Sending African Sunlight to Europe, Special Delivery. 12

13 Science, 329(5993), pp. 782-3. 13

14 Comité Intergouvernemental créé par la Conférence de Messine, 1956. 14

15 Rapport des Chefs de Délégation aux Ministres des Affaires Etrangères, 15

16 Brussels: Secrétariat. 16

17 Commission of the European Communities, 1988. The Internal Energy 17

18 Market, Brussels. 18

19 Coutard, O., 2001. Imaginaire et developpement des reseaux techniques: Les 19

20 apport de l'histoire de l'électrification rurale en France et aux Etats-Unis. 20

21 Réseaux, 5(109), pp. 76-94. 21

22 Eising, R., 2002. Policy Learning in Embedded Negotiations: Explaining EU 22

23 Electricity Liberalization. International Organization, 56(1), pp. 85-120. 23

24 Eising, R. and Jabko, N., 2001. Moving Targets: National Interests and Electricity 24

25 Liberalization in the European Union. Comparative Political Studies, 34(7), 25

26 pp. 742-67. 26

27 European Commission, 2001. Mededeling van de Commissie aan het Europees 27

28 Parlement en de Raad: 'Europese energie-infrastructuur'. Voorstel voor 28

29 en beschikking van het Europees Parlement en de Raad tot wijziging van 29

30 Beschikking $\mathrm{nr}$. 1254/96/E.G. tot opstelling van richtsnoeren voor trans- 30

$31 \quad$ Europese netwerken in de energiesector. Brussels. 31

32 Fleury, A., 1983. La Suisse et Radio Nations. In The League of Nations in 32

33 retrospect: Proceedings of the symposium. pp. 196-220. 33

34 Gilbert, R.J., Kahn, E.P. and Newberry, D.M., 1996. Introduction: International 34

35 Comparisons of Electricity Regulation. In R.J. Gilbert and E.P. Kahn, eds, 35

36 International Comparisons of Electricity Regulation. Cambridge: Cambridge 36

$37 \quad$ University Press, pp. 1-24. 37

38 Hausman, W., Wilkins, M. and Hertner, P., 2008. Global Electrification: 38

39 Multinational Enterprise and International Finance in the History of Light 39

40 and Power. Cambridge: Cambridge University Press. 40

41 Helm, D., 2002. Energy Policy: Security of Supply, Sustainability and Competition. 41

42 Energy Policy, 30(3), pp. 173-84. 42

43 Herf, J., 1984. Reactionary Modernism: Technology, Culture, and Politics in 43

$44 \quad$ Weimar and the Third Reich. Cambridge: Cambridge University Press. 44 
1 Von Hirschhausen, C., 2010. Developing a Supergrid. In B. Moselle, J. Padilla, 1 2 and R. Schmalensee, eds, Harnessing Renewable Energy in Electric Power 2 3 Systems: Theory, Practice, Policy. Washington, DC: Earthscan, pp. 181-206. 3 4 Hughes, T.P., 1987. The Evolution of Large Technical Systems. In W.E. Bijker, 4 5 T.P. Hughes, and T.J. Pinch, eds, The Social Construction of Technological 5 6 Systems. Cambridge, MA: MIT Press, pp. 51-82. 6

7 International Electrotechnical Commission, 1906. Report of Preliminary 7

8 Meeting, London. 8

9 Kaijser, A., 2003. Redirecting Infrasystems Towards Sustainabilty. In Individual 9

10 and Structural Determinants of Environmental Practice. Aldershot: Ashgate, 10

11 pp. 152-79. 11

12 Laak, D. van, 2004. Technological Infrastructure, Concepts and Consequences. 12

13 ICON, 10, pp. 53-64. 13

14 Lagendijk, V., 2008. Electrifying Europe: The Power of Europe in the Construction 14

15 of Electricity Networks, Amsterdam: Aksant. 15

16 Lagendijk, V., 2011. 'An Experience Forgotten Today': Examining Two Rounds 16

17 of European Electricity Liberalization. History and Technology, 27(3), 17

18 pp. 291-310. 18

19 Lagendijk, V., 2012. 'To Consolidate Peace'? The International Electro-Technical 19

20 Community and the Grid for the United States of Europe. Journal of 20

21 Contemporary History, 47(2). 21

22 Landry, P., 1926. Exchange of Electrical Energy Between Countries: General 22

23 Report on Section B. In Transactions of the World Power Conference, Basle 23

24 sectional meeting. Basle: E. Birkhäuser and Cie., pp. 1112-24. 24

25 League of Nations 1923a. Advisory and Technical Committee for Communications 25

26 and Transit, Procès-verbal of the second session, held at Geneva, 26

27 March 29th-31st, 1922. LoN doc. Ser. C.378.M.171.1923.VIII (Geneva: 27

28 League of Nations), Annex 7.

29 League of Nations 1923b. Second General Conference on Communications 29

30 and Transit. Electric Questions: Report concerning the draft Conventions 30

31 and Statutes Relating to the Transmission in Transit of Electric Power 31

32 and the Development of Hydraulic Power on Watercourses Forming Part 32

33 of a Basin Situated in the Territory of Several States. Vol 3. LoN doc. Ser. 33

34 C.378.M.171.1923.VIII (Geneva: League of Nations). 34

35 Mance, S.O., 1946. International Road Transport, Postal, Electricity and 35

36 Miscellaneous Questions, London: Oxford University Press. 36

37 Matláry, J.H., 1997. Energy Policy in the European Union, London: 37

$38 \quad$ Palgrave Macmillan. 38

39 North, D.C., 1990. Institutions, Institutional Change, and Economic Performance, 39

40 Cambridge: Cambridge University Press. 40

41 Padgett, S., 1992. The Single European Energy Market: The Politics of 41

42 Realization. Journal of Common Market Studies, 30(1), pp. 53-75. 42

43 Pepermans, G. et al., 2005. Distributed generation: definition, benefits and issues. 43

44 Energy Policy, 33(6), pp. 787-98. 44 
1 Pfaffenberger, B., 1990. The Harsh Facts of Hydraulics: Technology and Society in 1

2 Sri Lanka's Colonization Schemes. Technology and Culture, 31(3), pp. 361-97. 2

3 Pfaffenberger, B., 1992. Technological Dramas. Science, Technology and Human 3

$4 \quad$ Values, 17(3), pp. 282-312. 4

5 Rosenau, J.N., 1995. Governance in the Twenty-First Century. Global 5

6 Governance, 1(1), pp. 13-44. 6

7 Schipper, F., Lagendijk, V. and Anastasiadou, I., 2010. New Connections for 7

8 an Old Continent: Rail, Road and Electricity in the League of Nations' 8

9 Organisation for Communications and Transit. In A. Badenoch and A. Fickers, 9

10 eds. Europe Materializing? Transnational Infrastructures and the Project of 10

11 Europe. Houndsmills: Palgrave Macmillan, pp. 113-43. 11

12 Siegel, G., 1930. Die Elektrizitätsgesetzgebung der Kulturländer de Erde, 12

13 Berlin: VDI-Verlag. 13

14 Thue, L., forthcoming. Connections, Criticality, and Complexity: Norwegian 14

15 Electricity in its European Context. In Europe Goes Critical: The Emergence 15

16 and Governance of Transnational Infrastructure Vulnerabilities. Cambridge, 16

17 MA: MIT Press. 17

18 UCPTE, 1988. Rapport annuel 1986-1987, Heidelberg: UCPTE. - 18

19 UCTE, 2000. Rapport annuel 1999, Brussels: UCTE. 19

20 UCTE, 2002. Rapport annuel 2001, Brussels: UCTE. 20

21 Varaschin, D., 1997. Etats et électricité en Europe occidentale. Habilitation 21

22 à diriger des recherches. Habilitation. Université Pierre-Mendes-France: 22

23 Grenoble III. 23

$24 \quad 24$

$25-25$

$26 \quad 26$

$27 \quad 27$

$28-28$

$29-29$

$30-30$

$31 \quad 31$

$32 \quad 32$

$33 \longrightarrow 33$

$34-34$

$35-35$

$36 \quad 36$

$\begin{array}{ll}37 & 37\end{array}$

$38 \quad 38$

$39 \quad 39$

$40 \quad 40$

$41 \quad 41$

$42 \quad 42$

$43-43$

$44 \quad 44$ 